\title{
PENGARUH MOTIVASI MELALUI APLIKASI WHATSAPP TERHADAP PENGURANGAN JUMLAH BATANG ROKOK YANG DIHISAP OLEH PEROKOK AKTIF
}

The effect of motivation through the whatsapp application on the reduction of the number of cigarettes inhaled by active smokers

\author{
Alamsyah ${ }^{1}$, Jamilah Mirayanti ${ }^{2}$, Nurun Salaman ${ }^{3}$ \\ 1,2,3Akademi Keperawatan Pelamonia Kesdam VII/Wirabuana \\ alamakperpelamonia@gmail.com/085299900321
}

\begin{abstract}
Many people smoke just because of social factors without thinking about the bad effects it will have on their bodies, especially the respiratory system. Many teenagers smoke just because of social factors without thinking about the bad effects that will happen to their bodies, especially their respiratory system. The research method used was true experimental design using randomized pretest-posttest control group design. The results of the study using the Wilcoxon test showed that the two groups both showed significant results, namely $p=0.00<p=0.05$ which indicates that there is the influence of motivation to use video and WhatsApp in reducing the number of cigarettes inhaled by active smokers. Even though they both had the same results, the number of changes in the intervention group was more than the control group. The control group experienced a decrease by 26 people, while the control group was only 15 people. Conclusion, motivation to use video and WhatsApp is effective in reducing the number of cigarettes inhaled by active smokers..
\end{abstract}

Keywords : Motivation, Videos, WhatsApp, Reducing the Number of Cigarettes.

\section{ABSTRAK}

Banyak orang merokok hanya karena faktor pergaulan tanpa memikirkan dampak buruk yang akan terjadi pada tubuhnya terutama sistem pernafasannya. Banyak remaja merokok hanya karena faktor pergaulan tanpa memikirkan dampak buruk yang akan terjadi pada tubuhnya terutama sistem pernafasannya. Metode penelitian yang digunakan adalah true experimental design dengan menggunakan Randomized pretest-postest control group design.Hasil penelitian dengan menggunakan uji Uji Wilcoxon bahwa kedua kelompok sama-sama menunjukkan hasil yang signifikan yaitu $p=0,00<p=0,05$ yang menunjukkan bahwa ada pengaruh Motivasi Menggunakan Video dan WhatsApp dalam Menurunkan Jumlah Batang Rokok yang Di Hisap Oleh Perokok Aktif. Meskipun ada keduanya memiliki hasil yang sama namun jumlah perubahan kelompok Intervensi lebih banyak dibandingkan dengan kelompok control. Kelompok control mengalami penurunan sebanyak 26 orang sedangkan kelompok control hanya 15 orang. Kesimpulan, Motivasi Menggunakan Video dan WhatsApp efektif Menurunkan Jumlah Batang Rokok yang Di Hisap Oleh Perokok Aktif.

Kata kunci : Pemberian Motivasi, Video, WhatsApp, Pengurangan Jumlah Batang Rokok.

\section{PENDAHULUAN}

Merokok adalah menghisap asap tembakau yang dibakar ke dalam tubuh dan menghembuskannya kembali keluar (Jaya, M., 2009). Menurut World Health Organisation (Who) tahun 2015, terkait persentase penduduk dunia yang menkonsumsi tembakau didapatkan sebanyak $57 \%$ pada penduduk Asia dan Australia, $14 \%$ pada penduduk Eropa Timur dan Pecahan Uni Soviet, $12 \%$ penduduk Amerika, 9\% penduduk Eropa Barat dan 8\% pada penduduk Timur Tengah serta Afrika. Sementara itu ASEAN merupakan sebuah kawasan dengan $10 \%$ dari seluruh perokok dunia dan $20 \%$ kematian global akibat tembakau. Menurut Tobacco Atlas yang diterbitkan oleh WHO, merokok adalah penyebab bagi hampir 90\% kanker paru, $75 \%$ penyakit paru obstruktif kronis (PPOK), dan juga menjadi 25\% penyebab serangan jantung (Kemkes $\mathrm{RI}, 2013)$. Riset Kesehatan Dasar (Riskesdas) terbaru tahun 2018.

Persentase perilaku merokok remaja pada tahun 2018 tercatat sebesar 9,1 persen, meningkat dari Riskesdas 2013 yakni 7,2 persen. Sementara itu, Provinsi Sulawesi Selatan prevalensi perokok menurut umur $\geq 10$ tahun 2018 mencapai 25,7\%. Remaja menjadi objek tertinggi yang mengkomsumsi rokok, sehingga perlu cara untuk memberikan dorongan semangat kepada remaja untuk mengurangi komsumsi rokok. Salah satu cara terbaik adalah dengan memberikan motivasi. Motivasi dapat diartikan sebagai kekuatan (energi) seseorang yang dapat menimbulkan tingkat persistensi dan antusiasmennya dalam melaksanakan suatu kegiatan, baik yang bersumber dari dalam diri individu 
itu sendiri (motivasi intrinsik) maupun dari luar individu (motivasi ekstrinsik) (Winardi, 2011). Oleh karena itu, dalam memberikan motivasi untuk mengurangi jumlah batang rokok yang dihisap oleh perokok aktif, dapat dilakukan dengan cara yang mudah salah satunya adalah dengan cara melalui pemanfaatan Smartphone. Hasil Penelitian yang dilakukan oleh Grace Lewis dkk (2020), bahwa stigma dapat bertindak sebagai enabler dan penghalang dalam kelompok perokok. Pengurangan dalam merokok di rumah tergantung pada efikasi diri dan motivasi untuk berhenti merokok, dan stigma sangat berpengaruh terhadap keyakinan diri dalam mengontrol diri untuk berhenti merokok.

Penggunaan internet dan smartphone telah lama diteliti dan terbukti efektif meningkatkan status kesehatan masyarakat. Akses internet memudahkan masyarakat untuk mencari informasi dan pembelajaran spesifik. Pencarian informasi didominasi oleh pemanfatan internet melalui media smartphone. Tren ini menjadi peluang praktisi kesehatan untuk menyampaikan informasi kesehatan dengan media sosial (Boulos dkk, 2016 ; Maretska dkk, 2019).

Saat ini ada banyak alternatif yang bisa dilakukan untuk mengubah perilaku remaja dalam mengurangi komsumsi rokok. Penelitian yang dilakukan oleh Laila dkk (2016), bahwa setelah diberikan intervensi dengan menonton video tentang bahaya merokok dan melakukan tanya jawab dengan fasilitator, hampir seluruh peserta memahami bahaya asap rokok bagi kesehatan. Peserta awalnya tidak mengerti isi dari video yang diberikan namun setelah diberikandan penjelasan mengenai isi video yang ditayangkan, peserta akhirnya memahami bahwa asap rokok memang sangat berbahaya bagi kesehatan perokok aktif maupun perokok pasif. Oleh karena itu, penelitian tersebut masih perlu di kembangkan dengan membuat Focus Group Discussion (FGD) melalui media WhatsApp untuk memberikan banyak kesempatan pada peserta untuk melakukan tanya jawab terkait dengan rencana berhenti merokok.

WhatsApp adalah aplikasi populer dengan jumlah pengguna tertinggi di dunia. Pengguna WhatsApp dapat memanfaatkan fasilitas mengirim pesan, gambar, video dan video call hingga membuat kelompok diskusi. WhatsApp merupakan aplikasi yang paling sering digunakan dan dengan durasi yang paling lama oleh pengguna smartphone (Montag et al., 2015). Dari penjabaran tersebut diatas, peneliti mengambil keputusan untuk melakukan rencana penelitian

\section{METODE}

\section{Desain, tempat dan waktu}

Jenis penelitian yang digunakan adalah true experimental design yaitu jenis rancangan penelitian yang mempunyai ketelitian tinggi karena sampelnya dipilih secara acak dan ada kelompok kontrolnya.
Penelitian ini menggunakan Randomized pretestpostest control group design yaitu ada dua kelompok yang dipilh secara acak, lalu diberi pretest dan post test untuk mencari perbedaan dengan kelompok kontrol terhadap eksperimen yang akan dan telah digunakan.

Tempat penelitian ini tidak ditetapkan karena sampel yang menjadi subjek penelitian adalah masyarakat Sulawesi Selatan yang terdiri dari beberapa Kabupaten.

Waktu Penelitian ini mulai dari bulan Mei sampai Juli 2020.

Populasi dalam penelitian ini adalah semua perokok aktif yang ada di wilayah Provinsi Sulawesi Selatan. Jumlah subyek penelitian ini adalah sebanyak 62 orang yang terbagi masing-masing kelompok intervensi sebanyak 31 orang dan kelompok control sebanyak 31 orang. Penarikan sampel menggunakan simpel random sampling.

Proses penelitian dimulai dari penyaringan sampel dengan membagi kuesioner menggunakan Google Form secara acak, setelah itu diberikan lagi intervensi menggunakan aplikasi WhatsApp sebagai media Focus Group Discussion. Setelah itu akan diberikan kembali post test kepada kelompok control dan kelompok intervensi untuk mengukur jumlah batang rokok yang dihisap setelah diberikan intervensi.

\section{HASIL}

a. Distribusi Responden berdasarkan umur

\begin{tabular}{ccc}
\hline Jenis kelamin & $\mathbf{N}$ & $\%$ \\
\hline $15-20$ & 30 & 49.2 \\
\hline $21-25$ & 8 & 13.1 \\
\hline $26-30$ & 13 & 21.3 \\
\hline $31-35$ & 8 & 13.1 \\
\hline $36-40$ & 2 & 3.3 \\
\hline Total & 61 & 100.0 \\
\hline
\end{tabular}

Berdasarakan tabel 1 Responden umur 15-20 sebanyak 30 orang (49,2\%), umur $21-25$ sebanyak 8 orang (13,1\%), umur 26-30 sebanyak 13 orang $(21,3 \%)$, umur $31-35$ sebanyak 8 orang $(13,1 \%)$ sedangkan umur 36-40 tahun sebanyak 2 orang $(3,3 \%)$.

b. Distribusi responden berdasarkan pendidikan

\begin{tabular}{ccc}
\hline Pendidikan & N & $\%$ \\
\hline Magister (S2) & 2 & 3.3 \\
\hline Sarjana (S1) & 9 & 14.8 \\
\hline Diploma III (D3) & 7 & 11.5 \\
\hline Pelajar/Mahasiswa & 43 & 70.5 \\
\hline Total & 61 & 100 \\
\hline
\end{tabular}


Berdasarakan tabel diatas Responden umur 1520 sebanyak 30 orang $(49,2 \%)$, umur $21-25$ sebanyak 8 orang $(13,1 \%)$, umur $26-30$ sebanyak 13 orang $(21,3 \%)$, umur $31-35$ sebanyak 8 orang $(13,1 \%)$ sedangkan umur 36-40 tahun sebanyak 2 orang $(3,3 \%)$.

c. Distribusi responden berdasarkan pekerjaan

\begin{tabular}{ccc}
\hline Pekerjaan & N & $\%$ \\
\hline ASN/TNI/Polri & 13 & 21.3 \\
\hline Pegawai Swasta & 8 & 13.1 \\
\hline Wiraswasta & 3 & 4.9 \\
\hline Pelajar/Mahasiswa & 34 & 55.7 \\
\hline Tidak Bekerja & 3 & 4.9 \\
\hline Total & 61 & 100 \\
\hline
\end{tabular}

Berdasarakan tabel diatas pekerjaan responden yang paling banyak yaitu Pelajar/Mahasiswa dengan jumlah 34 orang $(55,7 \%)$, ASN sebanyak 13 orang $(21,3 \%)$, Pegawai Swasta sebanyak 8 orang $(13,1 \%)$, sedangkan responden yang paling sedikit yaitu Wiraswasta Sebanyak 3 orang $(4,9 \%)$ dan tidak bekerja sebanyak 3 orang $(4,9 \%)$.

d. Distribusi responden berdasarkan pendapatan

\begin{tabular}{lcc}
\hline \multicolumn{1}{c}{ Jenis kelamin } & $\mathbf{N}$ & $\%$ \\
\hline$>$ 3,5 Juta & 15 & 24.6 \\
\hline$>$ 2,5 Juta - 3,5 Juta & 7 & 11.5 \\
\hline$>$ 1 Juta $-2,4$ Juta & 3 & 4.9 \\
\hline$>$ 500.000 - 1 Juta & 4 & 6.6 \\
\hline$<500.000$ & 32 & 52.5 \\
\hline \multicolumn{1}{c}{ Total } & $\mathbf{6 1}$ & $\mathbf{1 0 0 . 0}$
\end{tabular}

Berdasarakan tabel diatas Responden berdasarkan penghasilan diatas 3,5 Juta sebanyak 15 orang $(24,6 \%)$, penghasilan diatas 2,5 Juta $-3,5$ Juta sebanyak 7 orang $(11,5 \%)$, penghasilan $>1$ Juta $-2,4$ Juta sebanyak 3 orang (4,9\%), penghasilan > 500.000 - 1 Juta sebanyak 4 orang ( $6,6 \%)$ sedangkan penghasilan $<500.000$ tahun sebanyak 32 orang $(52,3 \%)$.

\section{Analysis Univariat}

a. Mengetahui bahaya rokok terhadap Kesehatan

\begin{tabular}{|ccc|}
\hline Mengetahui & $\mathbf{N}$ & $\%$ \\
\hline Ya & 56 & 91,8 \\
\hline Tidak & 5 & 8,2 \\
\hline Total & 61 & 100.0 \\
\hline
\end{tabular}

Berdasarkan table tersebut diatas didapatkan data bahwa responden yang tahu bahaya rokok terhaap kesehatan berjumlah 56 orang $(91,8 \%)$ sedangkan responden yang tidak mengetahui bahaya rokok terhadap kesehatan berjumlah 5 orang $(8,2 \%)$

b. Keinginan responden untuk berhenti merokok

\begin{tabular}{|ccc|}
\hline Keinginan & N & $\%$ \\
\hline Ya & 49 & 80.3 \\
\hline Tidak & 12 & 19.7 \\
\hline Total & $\mathbf{6 1}$ & $\mathbf{1 0 0 . 0}$ \\
\hline
\end{tabular}

Berdasarkan table diatas didapatkan bahwa responden yang ingin berhenti merokok sebanyak 49 orang $(80,3 \%)$, sedangkan responden yang tidak ingin berhenti merokok sebanyak 12 orang $(19,7 \%)$

\section{Ranks}

\begin{tabular}{|c|c|c|c|c|c|c|}
\hline & & $\mathrm{N}$ & $\begin{array}{l}\text { Mean } \\
\text { Rank }\end{array}$ & $\begin{array}{l}\text { Sum Of } \\
\text { Ranks }\end{array}$ & Z & $\begin{array}{l}\text { Asymp } \\
\text { Sig. (2- } \\
\text { tailed) }\end{array}$ \\
\hline $\begin{array}{l}\text { Post Klp } \\
\text { Intervensi- } \\
\text { Pre Klp } \\
\text { Intervensi }\end{array}$ & $\begin{array}{l}\text { - Ranks } \\
+ \text { Ranks } \\
\text { Ties } \\
\text { Total }\end{array}$ & $\begin{array}{c}26 \\
0 \\
5 c \\
31\end{array}$ & 13.5 & 351,00 & -4.47 & .000 \\
\hline $\begin{array}{l}\text { Post Klp } \\
\text { Kontrol - } \\
\text { Pre Klp } \\
\text { Kontrol }\end{array}$ & $\begin{array}{l}\text { - Ranks } \\
+ \text { Ranks } \\
\text { Ties } \\
\text { Total }\end{array}$ & $\begin{array}{c}15 \\
2 \\
13 \\
30\end{array}$ & $\begin{array}{l}9.2 \\
7.5\end{array}$ & $\begin{array}{c}138 \\
15\end{array}$ & -2.98 & .003 \\
\hline
\end{tabular}

Berdasarkan dari data diatas menunjukkan bahwa antara kelompok intervensi dan control terdapat perbedaan perubahan jumlah yang di hisap oleh perokok aktif yaitu di Negatif Ranks sebanyak 26 orang artinya sebanyak 26 orng yang mengalami penurunan jumlah batang rokok yang dihisap oleh perokok aktif. Sementara yang bertambah 0 .

Selain itu hasil uji Wilcoxon menunjukkan hasil $p=0,00$ yang menunjukkan bahwa Ha diterima yang berarti 
bahwa ada pengaruh pemberian intervensi melalui video dan media watsapp terhadap penurunan jumlah batang rokok yang dihisap perokok aktif.

\section{PEMBAHASAN}

\section{a. Karakteristik responden}

Mayotitas umur responden adalah usia 15-30 tahun. Usia remaja merupakan usia yang sangat ideal dengan Masa transisi seringkali menghadapkan remaja pada situasi yang membuat remaja bingung, karena di satu pihak ia masih anak-anak dan di pihak lain harus bersikap dewasa. Hal tersebut dapat terjadi perubahan psikologi remaja yang dapat terlihat dari ketidakstabilan emosi ketika menghadapi sesuatu. Selain itu itu, Masa remaja juga mengalami perubahan fisik yang cepat termasuk perubahan hormone dan bentuk tubuh, yang dapat terlihat dari bertambah tinggi, berat badan, dan kematangan seksual (Notoatmojo, 2010).

Sementara pada pendidikan yang mayoritas menghisap rokok adalah Pelajar/Mahasiswa. Pendidikan adalah aktivitas dan usaha manusia untuk meningkatkan kepribadiannya dengan jalan membina potensi-potensi pribadi, yaitu rohani (pikir, rasa, karsa, cipta dan budi nurani). Tingkat kemampuan seseorang untuk melakukan adaptasi terhadap perubahan yang terjadi biasanya dipengaruhi oleh Kualitas individu. Kualitas seseorang dapat diukur secara normatif berdasarkan jenjang pendidikan formal yang sudah ditempuhnya. Individu dengan tingkat pendidikan yang tinggi akan berusaha meningkatkan kehidupan diri dan keluarganya agar mencapai tujuan hidup yang lebih baik dan berkualitas. Pendidikan merupakan salah satu indikator yang mampu menggambarkan kemampuan daya intelektual sumber daya manusia dalam berkarya sehingga perlu diperhatikan dalam menelaah potensi dari sekelompok penduduk (Juliansyah \& Rizal, 2018). Hal tersebut sejalan dengan penelitian yang dilakukan oleh Juliansyah \& Rizal (2018) bahwa pendidikan memiliki pengaruh terhadap kebiasaan merokok oleh remaja.

Pekerjaan dan pendapatan tidak menjamin seseorang untuk mengkomsumsi rokok. Buktinya dari jumlah responden, mayoritas perokok adalah yang tidak bekerja dan pendapatan kurang dari rp. 500.000. hal ini disebabkan karena jumlah responden yang dominan adalah pelajar dan tidak memiliki pekerjaan, sehingga masih bergantung dari pendapatan keluarga penanggungnya. b. Pengaruh Motivasi melalui Video dan WhatsApp terhadap penurunan jumlah batang rokok yang dihisap oleh perokok aktif.

Dari hasil uji Wilcoxon menunjukkan nilai $p=0,00$ pada penelitian menunjukkan bahwa pemberian Motivasi melalui Video dan WhatsApp efektif menurukan jumlah batang rokok yang dihisap oleh perokok aktif. Hal tersebut dapat dilihat dari jumlah penurunan yang diperlihatkan oleh grup intervensi dengan nilai $Z$ atau Based on Negatif Ranks yaitu - 4.472 yang menunjukkan nilai rata-rata penurunan jumlah batang rokok yang dihsap yaitu sebanyak 4-5 batang rokok. Jika dibandingkan dengan kelompok control dengan nilai Z atau Based on Negatif Ranks yaitu -2.983 yang berarti bahwa rata-rata penurunan jumlah batang rokok yang dihisap yaitu sebanyak 3 batang.

Dari kedua kelompok tersebut pada dasarnya sama-sama terjadi penurunan, namun letak perbedaanya adalah dari jumlah penurunan jumlah batang rokok responden yang berbeda yaitu pada kelompok intervensi sebanyak 26 orang yang mengalami penurunan sementara pada kelompok control sebanyak 15 orang. Selain itu, pada kelompok control ada yang bertambah jumlah batang yang dihisap yaitu 2 orang. Hal tersebut disebabkan oleh karena tingkat kemauan untuk berhenti merokok yang masih tinggi. Dari 61 responden, masih ada 12 orang yang tidak mau berhenti merokok.

Kesadaran dalam diri individu untuk berhenti merokok sangat mempengaruhi proses dan hasil akhirnya untuk berhenti merokok. Hal ini sejalan dengan penelitian yang dilakukan oleh Wiratini et al., (2019) bahwa Dalam merubah perilaku individu diperlukannya adanya kesiapan individu untuk merubah diri individu itu sendiri.Sehingga diharapkan dengan adanya peningkatan pengetahuan dan sikap remaja mengenai bahaya rokok, upaya mencegah dan upaya menghindari rokok dapat mempengaruhi tindakan remaja untuk menghindari rokok dan berhenti merokok. Hasil ini sejalan dengan penelitian yang dilakukan oleh Spohr et al., (2015) bahwa proses berhenti merokok bergantung pad self determinasi masing-masing individu.

Penelitian ini mengadopsi model intervensi Focus Group Discussion (FGD) dengan memanfaatkan media online berupa aplikasi WhatsApp. Proses FGD ini menjadi media konseling perokok untuk mengurangi komsumsi rokok atau berhenti merokok. Hal ini sejalan dengan penelitian yang dilakukan oleh Prasetiawan et al., (2016) bahwa Metode konseling tidak efektif dalam meningkatkan motivasi berhenti merokok siswa di SMA di Kecamatan Leaya dengan nilai $p$ value sebesar 1,000 . Penelitian lain yang 
dilakukan oleh Saputra \& Sary, (2013) yang menggunakan model transteoritik. Hasil penelitian tersebut menunjukkan bahwa Individu mulai merokok disebabkan oleh pe- ngaruh lingkungan sosial, seperti teman-teman, orang tua, dan media se- hingga diperlukan suatu konseling terhadap remaja, salah satu metode kon- seling dengan pendekatan model transteoritik. Dalam beberapa kajian, ter- bukti model transteoritik efektif dalam mengubah perilaku merokok pada remaja. Berdasarkan kajian tersebut, diharapkan para konselor dalam mem- berikan konseling hendaknya memperhatikan kesiapan klien dalam meng- ubah perilaku hidupnya (aktivitas fisik) sesuai dengan tahap-tahapan yang ada dalam model transteoritik. Penelitian lain yang serupa dengan penelitian ini yaitu penelitian yang dilakukan oleh (Ikhsan et al., 2012) bahwa pendidikan kesehatan bahaya merokok memiliki pengaruh yang signifikan terhadap perilaku mengurangi konsumsi rokok

\section{KESIMPULAN}

Dari hasil penelitian yang dilakukan ditemukan bahwa ada pengaruh Motivasi Menggunakan Video dan WhatsApp dalam Menurunkan Jumlah Batang Rokok yang Di Hisap Oleh Perokok Aktif. Kelompok control mengalami penurunan sebanyak 26 orang sedangkan kelompok control hanya 15 orang.

Motivasi Menggunakan Video dan WhatsApp efektif Menurunkan Jumlah Batang Rokok yang Di Hisap Oleh Perokok Aktif.

\section{SARAN}

Merokok merupakan tindakan yang dapat merusak kesehatan. Aktifitas distraksi bagi perokok aktif dapat dilakukan untuk membantu perokok untuk mengurangi jumlah batang rokok yang dihisap setiap hari

\section{UCAPAN TERIMA KASIH}

Terima kami ucapkan kepada semua pihak yang telah membantu dalam pelaksanaan penelitian ini.

\section{DAFTAR PUSTAKA}

Ikhsan, H., SKM., MM, A., \& SKM.M.Kes.Epid, P. (2012). Pengaruh Pendidikan Kesehatan Bahaya Merokok Terhadap Perilaku Mengurangi Konsumsi Rokok Pada Remaja (Studi Kasus Di Dukuh Kluweng Desa Kejambon Kecamatan Taman Kabupaten Pemalang). STIKES Telogorejo Semarang, 0(0), 1-7. http://ejournal.stikestelogorejo.ac.id/index.php/ilmukeperawatan/article/view/121

Juliansyah, E., \& Rizal, A. (2018). Faktor umur, pendidikan, dan pengetahuan dengan perilaku merokok di wilayah kerja Puskesmas Sungai Durian, Kabupaten Sintang. Visikes: Jurnal Kesehatan Masyarakat, 7(1), 92-107.

Jaya, M, (2009). Pembunuh Berbahaya Itu Bernama Rokok. Jakarta : Salemba Medika

Julina, J. (2017). Pengaruh Persepsi Dampak Merokok Dan Fear Appeal Terhadap Motivasi Berhenti Merokok Serta Implikasinya Pada Perilaku Merokok Mahasiswa Di Kota Pekanbaru. JURNAL AL-IQTISHAD, 13(1), 35-47.

Kamel Boulos, M., Giustini, D., \& Wheeler, S. (2016). Instagram and WhatsApp in health and healthcare: an overview. Future Internet, 8(3), 37. DOI: https://doi.org/10.3390/fi8030037 Diakses pada tanggal 06 Agustus 2019. Available From https://www.mdpi.com/1999-5903/8/3/37/htm

Kemenkes RI. (2018). Hasil utama riskesdas 2018. Jakarta: Kemenkes RI.

MaretzkA, A., Yusril, Y., \& Kasim, B. I. (2019). Hubungan Tingkat Penggunaan Smartphone Dengan Nyeri Kepala Primer Pada Mahasiswa Angkatan 2017-2018 Program Studi Pendidikan Dokter Universitas Sriwijaya (Doctoral dissertation, Sriwijaya University).I

Montag, C., Błaszkiewicz, K., Sariyska, R., Lachmann, B., Andone, I., Trendafilov, B. Markowetz, A. (2015). Smartphone usage in the 21st century: who is active on WhatsApp? BMC Research Notes, 8(1), 331. https://doi.org/10.1186/s13104-015- 1280-z.Diakses pada tanggal $07 \quad$ Agustus 2019.

Available From https://bmcresnotes.biomedcentral.com/articles/10.1186/s13104-015-1280-z www.kbb.web.id diakses pada tanggal 12 Agustus 2019.

Nur Ikwal Musaini, Y. (2012). Pengaruh Pendidikan Kesehatan Terhadap Pengetahuan Dan Sikap Merokok Pada 
Siswa Laki-Laki Kelas XI SMK Murni 1 Surakarta (Doctoral dissertation, Universitas Muhammadiyah Surakarta). $\begin{array}{lllll}\text { Diakses pada tanggal } 12 & \text { Agustus } 2020 . & \text { Available from }\end{array}$ https://publikasiilmiah.ums.ac.id/handle/11617/2945.

Prasetiawan, P., Sakka, A., \& Erawan, P. (2016). Efektivitas Metode Konseling Terhadap Perilaku Merokok Pada Siswa Sma Di Kecamatan Laeya Tahun 2015. Jurnal Ilmiah Mahasiswa Kesehatan Masyarakat Unsyiah, 1(2), 184274.

Pusat Promosi Kesehatan Kementrian Kesehatan RI. (2013). Dampak Merokok Terhadap Kesehatan Remaja I Smoking go Kills. (On line) diakses 09 Agustus 2019 Available From http://promkes.kemkes.go.id/

Rachmat, M., Thaha, R. M., \& Syafar, M. (2013). Perilaku merokok remaja sekolah menengah pertama. Kesmas: National Public Health Journal, 7(11), 502-508. Diakses pada tanggal 13 Agustus 2019. Available from http://journal.fkm.ui.ac.id/kesmas/article/view/363/362

Rahayuwati, L., Lukman, M., Rahayu, E., \& Ridwan, M. (2018). Program RIAS (Remaja Siaga Asap Rokok): Mencegah dan Mengatasi Adiksi Rokok pada Remaja di Cisaranten Kulon. Media Karya Kesehatan, 1(1). http://journal.unpad.ac.id/mkk/article/view/16863

Rochayati, A. S., \& Hidayat, E. (2015). Faktor-Faktor Yang Mempengaruhi Perilaku

Rosemary, R. (2018). Pilihan Media Pencari Informasi Kesehatan. Jurnal Komunikasi Global, 7(2), 169-182.. Journal Komunikasi global. http://e- repository.unsyiah.ac.id/JKG/article/view/11756

Saputra, A. M., \& Sary, N. M. (2013). Konseling Model Transteoritik dalam Perubahan Perilaku Merokok pada Remaja Counseling with the Transtheoritical Model in Changing Smoking Behavioral among Adolescents. Jurnal Kesehatan Masyarakat Nasional, 8(4), 152-157. https://media.neliti.com/media/publications/39540-IDkonseling-model-transteoritik-dalam-perubahan-perilaku-merokok-pada-remaja.pdf

Spohr, S. A., Nandy, R., Gandhiraj, D., Vemulapalli, A., Anne, S., \& Walters, S. T. (2015). Efficacy of SMS Text Message Interventions for Smoking Cessation: A Meta-Analysis. Journal of Substance Abuse Treatment, 56, 1-10. https://doi.org/10.1016/j.jsat.2015.01.011

WHO. (2015). "WHO Global Report on Trends in Prevalence of Tobacco Smoking".WHO

Winardi. (2011). "Motivasi dan Pemotivasian dalam Manajemen", Rajawali:Jakarta.

Wiratini, N. P. S., Yanti, N. L. P. E., \& Wijaya, A. A. N. T. (2019). COPING Ners Journal. COPING Ners Journal, 3(3), 61-67. https://ojs.unud.ac.id/index.php/coping/article/download/13882/12287/0 